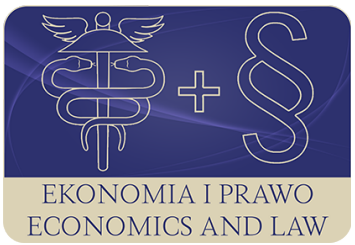

EKONOMIA I PRAWO. ECONOMICS AND LAW

Volume 17, Issue 3, September 2018

p-ISSN 1898-2255, e-ISSN 2392-1625

www.economicsandlaw.pl

ORIGINAL ARTICLE

received 02.01.2018; revised 26.04.2018; accepted 30.09.2018

Citation: Popowska, M., \& Ratkowska, B. (2018). Doing well by doing good — CSR in a global

context. Ekonomia i Prawo. Ecomomics and Law, 17(3): 289-305.

doi:10.12775/EiP.2018.021.

\title{
Doing well by doing good - CSR in a global context
}

\section{MAGDALENA POPOWSKA}

corresponding author

Gdańsk University of Technology, Faculty of Management and Economics, Department of Entrepreneurship and Business Law, ul. Narutowicza 11/12, 80-233 Gdańsk, Poland

$\square$ mpop@pg.edu.pl

\section{BEATA RATKOWSKA}

Independent researcher, Poland

$\square$ beata.ratkowska@gmail.com

\begin{abstract}
Motivation: Nowadays, there is a general understanding that stakeholders are crucial for the successful enterprise. There is also a need to think about Corporate Social Responsibility (CSR) in a global context. Never before corporations enjoyed so much power and authority. Corporations need to evolve, re-think their strategies and change their processes accordingly. However, as of now, there is no agreed way of measuring overall sustainability of actions of each company. There is a great need for holistic studies of CSR, analyzing in details the value created, from stakeholders point of view.

Aim: This paper is an attempt to propose a way of looking at corporate social responsibility in line with current methodologies and frameworks focusing on value creation. Currently there is no one definition of global CSR to be used, nor there is one comprehensive methodology to describe it. Instead there is abundance of theories and frameworks. This paper proposes one definition and presents a method of analysis of the global corporate commitment to CSR approach. The main concern of this paper is to offer an insight into different ways companies can create value for various stakeholders groups.

Results: Conducted analysis indicated that products companies are aware of needs and expectations of various stakeholders and are good at meeting them. Although assessed companies managed to link sustainability with their strategies, they did not achieve transforming sustainability into core of their business.
\end{abstract}


Keywords: CSR; sustainability; CSR reporting; CSR measuring; global CSR JEL: Q01

\section{Introduction}

'CSR is not a new concept. As long as business has existed, we have also had expectations from governments, stakeholders, NGO's and individuals concerning voluntary obligation to society' (Van der Laan Smith et al, 2005 as cited in Simpson \& Taylor, 2013).

Recently, CSR has drawn a particular public attention. Various scandals, including Enron and collapse of Arthur Andersen left their mark. It has been understood that there is something not quite right with corporate world and that these problems need to be addressed (Kotler et al., 2012). The need for a more responsible basis on which businesses and economies compete in international markets has never been greater (Zadek \& McGillivray, 2008) The global world of today means higher inequality between the rich and the poor, rising number of economically underprivileged societies, as well as tougher international competition, lower transparency and blurring accountability of businesses. There is an urgent need to address the environmental and societal challenges brought by open markets and current business practices- innovative strategies and forward thinking should be aligned to ensure responsible maximization of profit, rather than CSR being viewed as a way to maintain reputation or a reactive PR tool. Only cohesive transformation to welcome an era of 'responsible competitiveness' in global markets would guarantee the lasting impact of corporate social responsibility actions. Responsible competitiveness strategies are defined as ones that can reshape tomorrow's global markets in ways that take social and environmental issues into account (Mermod \& Idowu, 2014).

Achieving this, however, necessitates more than quick-moving businesses working alone. Overcoming the resistance of backward looking business and political interests will require innovative collaboration that combines smart public policies, with aligned business and civil society strategies, creating a new generation of market practices, norms, and standards (Zadek, 2008b, pp. 374-388). Despite companies like NIKE or Levi's securing safe work environments, (these two are premium brands targeting wealthier, environmentally-conscious consumers), poor work conditions of apparel factories in Asia have recently caught media attention after one of such factories collapsed killing hundreds of people. Couple of companies 'doing good' is simply not enough, as a systematic and significant change of whole industries and economies should be put in place. On average, fashion retail sector still lacks strongly enforced standards of ethical production. Worth mentioning is the fact that things are slowly improving for apparel industry thanks to co-operations between NGO's, governments and private sector in form of different initiatives: the Fair Labor Association, the Ethical Trading Initiative, and Social Accountability International to name 
a few, focused on providing scrutiny and guidance, creating codes of conducts and setting reporting standards (Zadek \& McGillivray, 2008).

What can be definitely observed now, is also the increased interest in companies' stakeholders (Smith et al., 2010). To a great extent they now shape corporate strategies and how the operations are running. This is also visible in sustainability reports which are very often concentrated around value created for different stakeholders. Moreover, globalization - increasing expansion, entering new markets, working from partners from all over the world and selling globally — demands global CSR strategies that will take into consideration local specifics.

Therefore, the main purpose of this paper is to offer an insight into different ways companies can create value for various stakeholders groups in the international context and in particular at the global level. This paper proposes also definition of the global CSR and presents a novel method of analysis of the global corporate commitment to CSR approach.

\section{CSR in a global perspective}

There is doubt, that nowadays there is a high pressure on large businesses to be socially responsible. According to McKinsey \& Company (2007) research conducted among companies taking part in the UN Global Compact, the most important factors influencing social expectation towards business are: increasing environmental degradation; scarcity of natural resources; rise of emerging economies (e.g. China, India). Also, globalization has a not-to-be-missed importance for CSR as it highlights and amplifies good and bad sides of corporate conduct. Global business environment, global supply chains and global stakeholders demand global CSR strategies. McKinsey \& Company (2007) research showed also which areas are the most pressing ones for CEOs nowadays when it comes to socially responsible business. The ones rated as the most important were: educational gaps; inefficient public governance; climate change; improving lives of the poor; stable energy supply. Companies are aware that 'if they can't measure it, they can't manage it' and constantly seek for better methods to track and benchmark sustainability.

There is an increasing pressure on companies to be transparent, mostly connected with a growing demand from governments, investigative journalism or an active work of NGO. Hence, the is a need of global transparency regulations and accountability standards. This results in increasing number of firms, which are disclosing more and more information and therefore can be kept more and more accountable for their actions. The growth of importance of sustainability reporting in recent years is undeniable. Usefulness of the reports is determined of its content, scope, and format, as well as transparency, accuracy and relevance of data (Brockett \& Rezaee, 2012). Therefore, it is possible to identify numerous sources of sustainability information, including companies 
themselves, professional data providers, sustainability research firms, pension consultants, investment firms and finally NGOs.

Very important for understanding sustainability is also the way CSR impact is measured. To understand connection between sustainability and performance, specially designed key performance indicators (KPIs) can be used. KPIs help to understand and track current CSR performance and show rooms for future improvements. Metrics are typically divided into financial and non-financial. Financial key performance indicators are these that deal with information that can be measured in monetary values and reflect key financial positions and results of operations. Non-financial KPIs are relevant to information that cannot be measured in monetary values. Despite the value of clearly defined operational KPIs, many companies do not report on them properly (Brockett \& Rezaee, 2012).

Additionally, the pressure put on companies to measure every CSR action sometimes backfires. Brockett and Rezaee (2012) defined five risks connected with sustainability: strategic, operations, compliance, finance, and reputation. All these risks place a serious threat to company well-being. Moreover, quality of reported data and measures is often questionable. Thus, good practice to increase reliability and relevance is to allow third-party audits and independent checks, usually by accounting firms traditionally offering auditing of financial statements. Worth mentioning is also the effect of global call for business accountability known as 'data fatigue' - overload of granular data available, what makes it hard to analyze all the information (The Economist, 2005).

The United Nations Global Compact (2014) in its flagship publication called Guide to corporate sustainability defines actions that must be taken by a company in order to become sustainable (table 1 ).

The interpretation of CSR varies depending on the company. Some take advantage of it to improve reputation/brand image while making profits, other think it can be useful in mediating risks and providing an important learning opportunity. Therefore, it's crucial for them to align CSR activities with their long-term strategy, and there is even this small group of innovators who make their business around CSR. Thus, it is possible to distinguish three generations of corporate responsibility, where compliance and risk management comprise First Generation, strategy and innovation become important in Second Generation, and, last but not least, Third Generation is concerned with transforming markets (Zadek, 2008a). A complimentary view is offered by an article in Harvard Business Review called The sustainability imperative (Lubin \& Esty, 2010). There are defined stages through which company goes while transforming itself into truly socially responsible business (table 2).

The approach of generations and the idea of stages are very similar, however there is a shift of perspective in the two models. Zadek's is more descriptive and generic, while the study of Lubin \& Esty (2010) offers more practical approach, sort of a guideline for companies on how to become sustainability leaders. Mapping of the two approaches is shown in the scheme 1. 
Regardless of generation/stage the company is in, it must execute chosen CSR practice with excellence. Each firm 'must climb the execution curve' (Lubin \& Esty, 2010). Evaluating CSR requires investigating whether a company does all it can in terms of chosen options and internal capabilities. The managerial excellence consists of all the processes and policies, beliefs and patterns of leadership. Options concern what drives CSR and which kind of optic (short term or long term) applies. Each company has to make numerous decisions connected with sustainability within its range of options. As the potential for making sustainability the source of competitive advantage of every company, an ultimate goal of every company should be to make the best use of its own sustainability potential (Zadek, 2004). In this approach, companies fall into one of four categories: they are either Losers or Defenders or Dreamers or Winners based on how they create value from CSR and how well do they perform.

The need to design proper CSR reporting and metrics for it is undeniable. However, there is no agreement in terms of how it should be done. According to KPMG (2014), new KPIs and measures should be developed as the ones currently in use are insufficient. 'It is clear that new metrics are required for companies to quantify their societal value creation and communicate the potential impacts of that societal value on financial performance. Without such metrics, investors do not have enough information to make a robust link between corporate and societal value creation'. The authors of this paper do not agree fully. CSR is difficult to fully grasp - there is not one widely-recognized definition to begin with and, as a consequence, there is not one way to measure sustainability. Companies try to respond to the pressure of transparency and accountability and publish some sustainability metrics. Examples of such measurements are: energy efficiency, filling rate for transport of products, number of employees, profit before tax, etc. There is no alliance when it comes to disclosing data, each company has its own KPIs to measure CSR, so making any comparison without getting additional data sources is impossible.

\section{Methods}

Currently there is no one definition of global CSR to be used, nor there is one comprehensive methodology to describe it. Instead there is abundance of theories and frameworks. Therefore, for the purpose of this work, the following global CSR definition was used - all global corporate actions impacting stakeholders connected with responsible conducting of business.

When it comes to the choice of industry sector, we decided to focus on products industry (encompassing both retail, consumer goods, and automotive), for two reasons: this is the sector, the authors know best and this sector is naturally dependent on stakeholders' engagement and meeting their expectations. Although, energy and utility sectors pioneered in reporting the environmental impact of their actions, in products the link between CSR and corporate performance is the most recognizable. 
Analysis was conducted with sample of 13 companies from products sector: 10 of these companies were identified as potential sustainability leaders. This assessment was based on recognition in different publications, and in particular on the scores in four rankings: Corporate Knights (2015) Global 100, Reputation Institute's (2014) Global CSR RepTrak, Interbrand's (2014) Best global green brands, and Newsweek's (2014) Green global ranking top 100 as shown in table 3. Remaining 3 - Timberland, The Body Shop, and Mars Inc. - were chosen as control sample as they did not figure out in any of the reports, however they were included as they are mentioned in other publications as companies that are very good at sustainability. The potential sustainability leaders were identified to represent, as much as possible, different branches (fashion/sport retailing, home furnishing, consumer electronics, automobiles, beverage producers and consumer goods) and different regions (North America, Europe, Asia).

In the next steps, companies were assessed on two levels: CSR execution capacities and value creation following the idea presented in the article The sustainability imperative (Lubin \& Esty, 2010). This two-dimensional analysis emerged companies that are the so-called 'sustainability leaders' in products industry companies that understood the needs of their stakeholders and leverage CSR to the best of their abilities.

After looking closely into numerous sustainability reports and websites, 60 actions were recognized as comprising a sustainability catalogue in products industry. However, these actions are just a fraction of endless sustainability possibilities. Each of the actions was characterized, except for the category, by a number of describing factors based on different theories such as: dimension (environmental, economic, social, ethical, and legal), type (cause promotions, cause-related marketing, corporate social marketing, corporate social initiatives, corporate philanthropy, workforce volunteering and socially responsible business practices), main area of impact (climate change, product safety, or work conditions), value chain part/ industry factors impacted (according to the Porter and Kramer outside-in and inside-in views). Must be noted that the all of the analysed actions are directly connected with company strategy, mission, and capabilities. The right mix of these actions determines how successful CSR agenda of a particular company will be and as a result set down its competitive advantage or lack of such in products industry.

The analysis comprised of two parts: first check was to determine whether the action is done based on company report on sustainability or dedicated website, secondly for each of the actions scores ranging from 0 to 4 were assigned in accordance to the concept of stages mentioned by Lubin \& Esty (2010) (table 4).

All data were self-reported as it came either from sustainability reports published by companies or from dedicated websites. 


\section{Results}

The world of CSR is definitely changing. Global challenges call for comprehensive solutions and are the land of opportunities for companies that will not only understand but also turn the possibilities of global CSR into real value. The challenge for companies is to learn how to embrace the change.

Currently all analysed companies in CSR and sustainability reporting focus on the various stakeholders. The initial step of this must be therefore to understand what they want from the companies, what their interests are and how they think. Stakeholder theory in practice means that there is a shift in thinking towards better understanding motives and wider world-view of different stakeholders, rather than simply looking at their behaviours. All of the analysed companies report in this manner, some has even directly shown mapping of their actions and stakeholders interest as in case of Sony Group (2014) or Samsung (2017). Samsung understands that having so many different stakeholders with often opposite ambitions and needs means that company must seek for a balanced strategy, incorporating all the different perspectives and shaping one unified strategy. Samsung highlights the need of harmony and collaborative creation of sustainable value through creativity, win-win partnership, and innovations. To better understand its stakeholders, in 2011 L'Oréal started organizing forums with NGOs and all sorts of association to get feedback on the corporate sustainability agenda. For Procter \& Gamble (2014), the most important for sustainable business are company's brands and people. Creating the best possible products and attracting the best employees guarantees consumer satisfaction and loyalty. P\&G believes that CSR value is created mostly within company and so the company designed a set of values oriented to improve lives of consumers in every corner of the world.

By looking at variety of corporate sustainability actions, commitment to the cause can be assessed. Also, it allows understanding the capacity of degree of devotion of companies towards CSR (table 5).

Analysed companies scored the highest at co-operation with suppliers. Most of the companies has a variety of suppliers from all over the world and so is trying to closely monitor how they approach sustainability issue. Hence, the popularity of suppliers' codes of conduct is growing, more and more sublime forms of conducting audits and assessments are occurring and general interest in work conditions offered to workforce, especially in developing countries is adding pressure. Companies also embrace sustainability with their factory and transport setup. Almost all companies published information on their action aiming at improving production and transport - reducing waste, improving work conditions, use of multimodal transportation, increasing fill rate, or using innovative system saving energy and water in plants. Current trend of growing awareness of how to report CSR is also reflected in high score of reporting. Companies use sustainability reports and metrics not to 'throw; data, but publish a comprehensive stance toward sustainability for their stakeholders. Ma- 
jority of companies have website dedicated to CSR, where news, success stories, recent trends and analysis are published. Some even use social media channels specifically to support their sustainability agenda. Almost all companies follow the global reporting standards (mostly GRI G4) and use current methodologies such as UNs' Global Compact. Last but not least, products companies have capacity to change thanks to global CSR the core of their business - their products. Current trend is to use recycled, renewable or organic product, to search new, more sustainable alternatives to traditional materials through innovation and product development. Companies also recycle and re-use their own products and packaging. A good example is packaging of products that is more and more often reduced, in neutral colours (colourful products use more energy in production process) and recyclable. Scores for company inner policies and treatment of employees were worse than expected, however this is mostly due to long-term change of rules required, for instance in case of $\%$ of women in leadership that in many cases was far from equal to men or offering employees paid volunteer opportunities. When it comes to partnerships and philanthropy quite much is being done, however in these two spheres actions were the most dispersed and not connected with strategy. The authors of this paper believe that global companies have resources and means to establish closer collaborations, especially in terms of collaboration with competitors there is more that can be done. CSR execution capacity was also measured separately for each company (chart 1 ).

The highest in CSR execution capacity scored Coca-Cola and NIKE with $88 \%$ both. Very high capacity ( $\geq 80 \%)$ had also P\&G, IKEA and BMW. Leaders in this dimension embrace diversity of their actions and are aware that only the complex sustainability agenda respecting needs of all stakeholders is a key to success.

Last place with score little above $50 \%$ belongs to The Body Shop. Although The Body Shop is very active player in the sustainability game, the company concentrates its efforts on five value pillars: principles of active self-esteem, standing against animal testing, supporting community fair trade, defending human rights and protecting the planet (The Body Shop, 2013).

The second dimension of sustainability companies were assessed against was how much value they create with their actions. As the authors of this article strongly believe, not only quality but also quantity of actions matters. Therefore, the second area of focus was qualifying CSR actions. As mentioned in the research methodology section scores range from 0 to 4 , where 4 meant the highest possible engagement in certain group of actions. Scores were not assigned to single action, but to the whole category to reflect the overall value created in certain area/for certain stakeholder (table 6).

In terms of value creation companies scores balanced between 2.5-2.9, so were between stages understood as 'do new things in new ways' (stage 2) and 'transform core business' (stage 3). This means that when value creation is concern they belong to second generation ('strategic corporate responsibil- 
ity') according to Zadek's theory of generations. The highest value creation is associated with company category. Assessed firms achieved average score equal to 2.9 meaning they approach to company setup and inner policies was characterized by innovation and value in this area was well-captured. All companies developed unique way of thinking about sustainability that resulted in creating special mechanism to support it. Many established a position of CSO, however often named differently as in case of Timberland - Director of Sustainability or The Body Shop - International Director of Corporate Sustainability and Campaigns. Many have clear defined values such as Corporate Citizenship, Integrity, Leadership, Responsibility (Mars Inc.), Trust, etc. that guide their corporate behaviour. The leaders in this category - Timberland and The Body Shop - went an extra mile with promoting sustainability and the notion of responsible company making CSR the centre of their business. Sustainability is in these companies' DNA. Second best, Factory + transport category had a little different characteristic as there was no company that acts in a truly extraordinary sustainable way. However, almost all companies did something beyond average when it comes to action such as waste reduction (e.g. zero waste programs with no manufacturing waste left), 'green' design of factories (e.g. installation of solar panels, use of $100 \%$ renewable energy for manufacturing), or communicating with customers (e.g. SMS system dedicated to receiving feedback on sustainability agenda, social media channels dedicated to sustainability, responsible advertising and promoting sustainability in communities). Third best score was achieved for value creation from philanthropy. Most companies understood how important is helping communities, not only by one-time support for instance in time of catastrophe such as earthquake, flood or fire, but also by long-term actions such as fulfilling the basic needs of community members by providing access to hygiene, healthcare, education, work and the most sophisticated ones such as for example promoting responsible women body image (L'Oréal). CSR value creation, apart from being measured as category average, was also measured per company (chart 2).

The highest score for this dimension was achieved by NIKE Inc.; however differences between top 4 companies (NIKE Inc., Coca-Cola Company, Adidas Group and IKEA) weren't very big. Other companies which scored lower also created value for their stakeholders but didn't make such a strong connection between their strategy and sustainability agenda or value creation varied depending on stakeholder considered.

The overall scores for CSR execution capacity and CSR value creation were later combined and average from the two was calculated to get the overview of each company's sustainability maturity (chart 3 ).

The best scores in sustainability strategy and execution were achieved by two American companies: NIKE Inc. and Coca-Cola Company. Both companies scored above $80 \%$. Third place belong to Swedish furniture manufacturer, IKEA. These companies show that they can respond well to the expectations of their stakeholders. None of the analysed companies enter what is called 
in The sustainability imperative (Lubin \& Esty, 2010) article the stage 4 of sustainability ('new business model creation and differentiation' or third generation ('responsible competitiveness') of sustainable business according to Zadek's (2008a) theory of generations. This means that, although they are very engaged in CSR, they innovate and alter their products and thinking accordingly, they contribution stops at aligning sustainability into their strategy. God example is BMW with its Corporate Strategy Number ONE established in 2007 (BMW Group, 2014) - sustainability is shown as the integral part of the core principles of growth, shaping the future, profitability and access to new technologies and customers. BMW also recognizes the link between CSR and competitive advantage of the company.

What CSR leaders in products industry do differently is the way they approach sustainability - not as a way to create bigger returns for them, but rather as an opportunity to communicate with and serve their various stakeholders. Good example here is NIKE Inc. (2017) 'Over time, we've moved from viewing corporate responsibility as a necessity for managing risk to seeing it as an opportunity to create value for our business and innovate for a better world'. To increase CSR value creation companies should follow the NIKE example and make sustainability the basis of innovation in product and strategy design as well as in operations running.

\section{Conclusion}

Global CSR should be seen as a natural continuation of corporate social agenda started in 1960s. Recent shift toward viewing sustainability in a global context is a response to the impact of globalization on the corporate environment. The change in thinking about the sustainability was spotted by the companies which have done a lot to change accordingly to the new rules of the game. The highest CSR maturity has been achieved yet by small number of a first movers, who found ways to create new business models around sustainability. Such companies have an important role to play in pushing the whole industries to change accordingly. However, most companies so far have embraced the benefits of sustainable innovation and learning and of the alignment between CSR and strategy, but hasn't go through the deep change of core activity. This is clearly visible in the example of sustainability leaders from products industry. These corporations have the CSR execution capacity to create value for their stakeholders, however they haven't gone through radical change of their core activity. Instead they are slowly evolving into increasing CSR value creation in their value chain. The most sustainable firms from the group of analysed companies, NIKE Inc., Coca-Cola Company and IKEA, outstand other firms in terms of sophistication of ways of sustainable value creation. These companies consequently transform and innovate to bring value to all stakeholders through comprehensive portfolio of actions. They understand the wide social and environmental responsibilities 
imposed by various stakeholders and respond by carrying out well-thought CSR agenda.

Global CSR a relatively new phenomenon definitely needs further investigation, especially with practical recommendations to be followed by companies given the specifics of different industries.

\section{References}

BMW Group. (2014). Sustainable value report 2014. Retrieved 18.01.2017 from https://ddd.uab.cat.

Brockett, A.M., \& Rezaee, Z. (2012). Corporate sustainability: integrating performance and reporting. New Jersey: John Wiley \& Sons. doi:10.1002/9781119202899.

Corporate Knights. (2015). 2015 global 100 results. Retrieved 25.04.2018 from http://www.corporateknights.com.

Interbrand. (2014). 4th annual best global green brands 2014. Retrieved 15.01.2017 from http://interbrand.com.

Kotler, Ph., Hessekiel, D., \& Lee, N.R. (2012). Good works! Marketing and corporate initiatives that build a better world and the bottom line. New Jersey: John Wiley \& Sons. doi:10.1002/9781119205210.

KPMG. (2014). Corporate responsibility at KPMG - Community Investment web page. Retrieved 25.04.2018 from http://www.kpmg.com.

Lubin, D.A., \& Esty, D.C. (2010). The sustainability imperative. Harvard Business Review, May.

McKinsey \& Company. (2007). Shaping the new rules of competition: UN global compact participant mirror. Retrieved 25.04.2018 from https://www.unglobalcompact.org.

Mermod, A.Y., \& Idowu, S.O. (Eds.). (2014). Corporate social responsibility in the globalbusinessworld. Berlin:Springer. doi:10.1007/978-3-642-37620-7.

Newsweek. (2014). Green ranking global top 100. Retrieved 15.01.2017 from https://www.rankingthebrands.com.

NIKE. (2017). Retrieved 11.01.2017 from https://about.nike.com.

Procter \& Gamble. (2014). Sustainability report. Retrieved 25.04.2018 from http://www.pg.com.

Reputation Institute. (2014). Global CSR RepTrak ${ }^{\circledR} 100$ report. Retrieved 25.04.2018 from http://www.reputationinstitute.com.

Samsung. (2017). Retrieved 23.01.2017 from http://www.samsung.com.

Simpson, J., \& Taylor, J. (2013). Corporate governance, ethics and CSR. LondonPhiladelphia-New Delhi: Kogan Page.

Smith, N.C., Bhattacharya, C.B., Vogel, D., \& Levine, D.I. (Eds.). (2010). Global challenges in responsible business. Cambridge: Cambridge University Press. doi:10.1017/CBO9780511777660.

Sony. (2014). CSR reporting 2014. Retrieved 21.01.2017 from https:/ / www.sony. net. 
The Body Shop. (2013). Body Shop values report 2011-2013. Retrieved 25.04.2018 from http://www.thebodyshop.co.uk.

The Economist. (2005). The good company. Retrieved 25.04.2018 from http:// www.economist.com.

United Nations Global Compact. (2014). Guide to corporate sustainability. Retrieved 25.04.2018 from https://www.unglobalcompact.org.

Zadek, S. (2004). The path to corporate responsibility. Harvard Business Review, December.

Zadek, S. (2008a). Collaborative governance: the new multilateralism for the 21st century. In L. Brainard, \& D. Chollet (Eds.), Global development 2.0. Can philanthropists, the public, and the poor make poverty history? Washington: Brookings Institute.

Zadek, S. (2008b). Global collaborative governance: there is no alternative. Corporate Governance: The International Journal of Business in Society, 8(4). doi:10.1108/14720700810899121.

Zadek, S., \& McGillivray, A. (2008). Responsible competitiveness: making sustainability count in global markets. Harvard International Review, summer.

\section{Acknowledgements}

Author contributions: authors have given an approval to the final version of the article. Authors contributed to this work as follows: M.P. developed the concept and designed the study, B.R. collected the data, M.P. analysed and interpreted the data, B.R. prepared draft of article, M.P. revised the article critically for important intellectual content.

Funding: this research was fully funded by the Gdańsk University of Technology, Faculty of Management and Economics statutory sources.

Note: the results of this study were presented at 9th International Conference on Applied Economics Contemporary Issues in Economy (June 22-23, Torun, Poland). 


\section{Appendix}

\section{Table 1.}

\section{Five components of CSR strategy of a company}

\begin{tabular}{ll}
\hline \multicolumn{1}{c}{ Component } & \multicolumn{1}{c}{ Short definition } \\
\hline $\begin{array}{l}\text { principled business } \\
\text { strengthening society }\end{array}$ & $\begin{array}{l}\text { at the heart of sustainability lies integrity and basic ethics } \\
\text { company must operate having its influence on welfare and wellbeing of societies } \\
\text { in consideration } \\
\text { leadership commitment } \\
\text { reporting progress }\end{array}$ \\
$\begin{array}{l}\text { sustainability should be strongly supported by C-Suite } \\
\text { proper reporting should be emplaced to held company accountable for its commitment } \\
\text { to sustainability action } \\
\text { every action has a sever consequence on the local level and so the uniqueness of each } \\
\text { region of operations must be understood }\end{array}$ \\
\hline
\end{tabular}

Source: Own preparation based on United Nations Global Compact (2014).

Table 2.

Stages of corporate social responsibility

\begin{tabular}{lll}
\hline \multicolumn{1}{c}{ Stage } & \multicolumn{1}{c}{ Main objectives } & \multicolumn{1}{c}{ Example } \\
\hline l: do old things in new ways & competing on regulatory compliance & 3M's Pollution Prevention Pays \\
& reducing environment-related costs & \\
& risk management & \\
2: do new things in new ways & sustainable products & DuPont's Zero Waste \\
& sustainable processes & \\
& sustainable value chains & \\
3: transform core business & CSR as a source of new revenues & Dow's 2015 Sustainability \\
& growth through CSR & Goals \\
4: new business model creation and dif- & sustainability leaders & GE's Ecomagination initiative \\
ferentiation & CSR embedded in strategy & \\
\hline
\end{tabular}

Source: Lubin \& Esty (2010). 
Table 3.

Position of companies used for analysis in different rankings

\begin{tabular}{lcccc}
\hline Companies/ Brands & $\begin{array}{c}\text { Global CSR RepTrak } \\
\text { position }\end{array}$ & Global 100 & $\begin{array}{c}\text { Best Global Green } \\
\text { Brands }\end{array}$ & $\begin{array}{c}\text { Green Ranking } \\
\text { Global Top 100 }\end{array}$ \\
\hline Adidas & 16 & 3 & 8 & 17 \\
BMW & 4 & 6 & 13 & 16 \\
Coca-Cola Company & 28 & 26 & 20 & - \\
Daimler & 10 & 60 & - & 39 \\
IKEA & 26 & - & 19 & - \\
L'Oréal & 49 & 14 & 22 & 35 \\
NIKE Inc. & 61 & - & 29 & - \\
Procter \& Gamble & 31 & - & - & 76 \\
Samsung Electronics & 16 & 45 & 11 & - \\
Sony & 11 & - & 7 & - \\
\hline
\end{tabular}

Source: Own preparation based on Corporate Knights (2015); Reputation Institute (2014); Interbrand (2014); Newsweek (2014).

Table 4.

CSR value scoring

\begin{tabular}{lcc}
\hline Score & Meaning & Sustainable stage \\
\hline 0 & not done & - \\
1 & basic level & do old things in new ways \\
2 & sustainable compliance & do new things in new ways \\
3 & innovative approach & transform core business \\
4 & sustainability leader & new business model creation and differentiation \\
\hline
\end{tabular}

Source: Own preparation based on Lubin \& Esty (2010). 

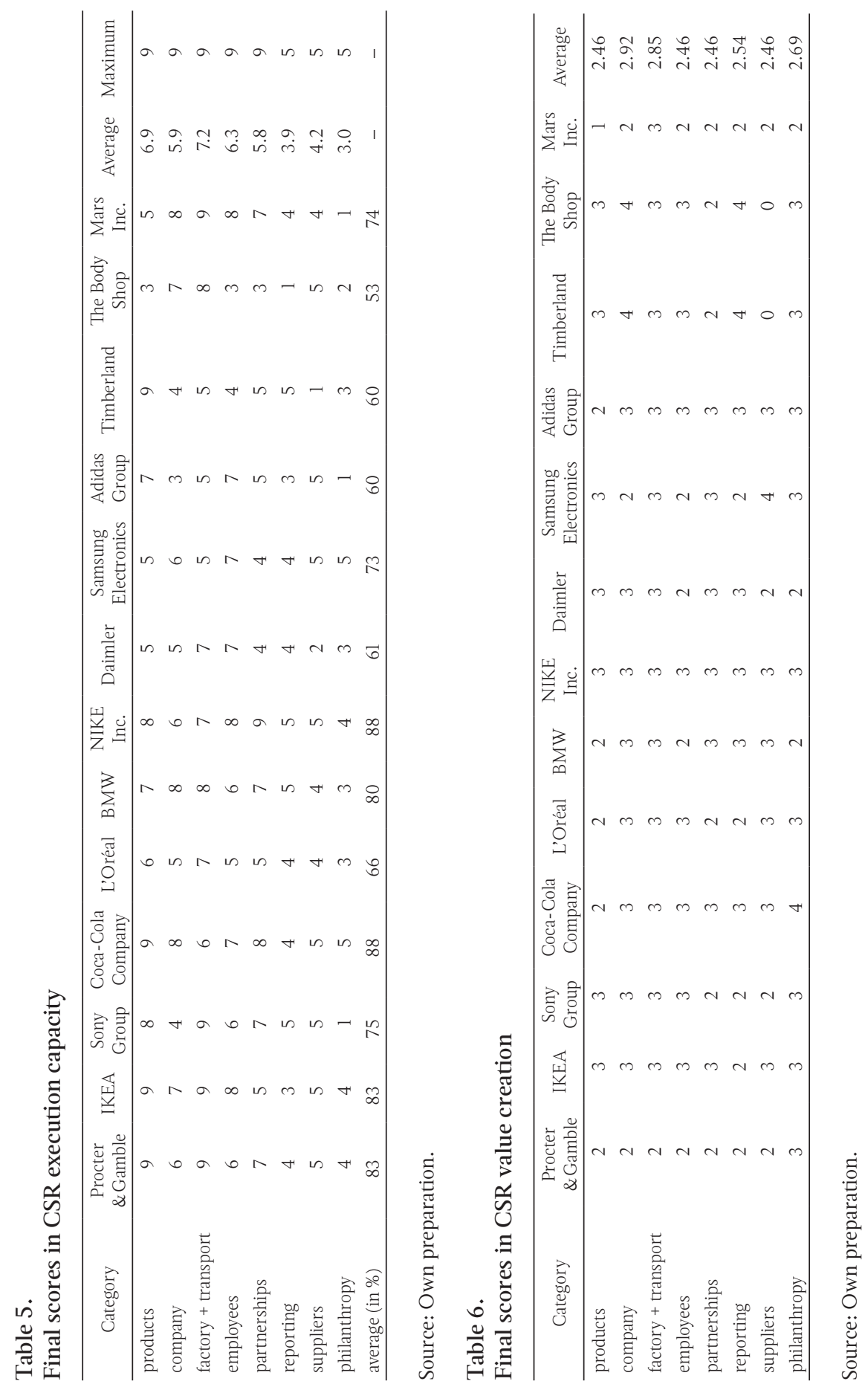
Scheme 1 .

Mapping of Zadek's theory of CSR generations and stage model.

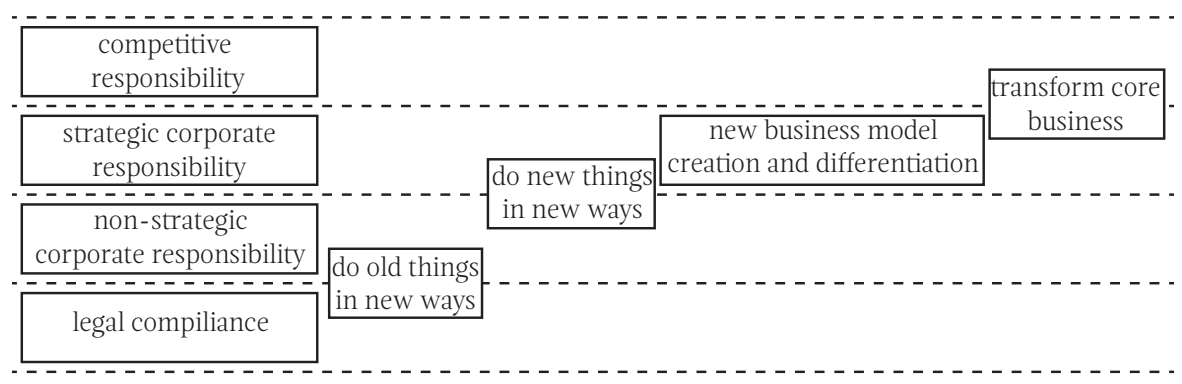

Source: own based on Zadek (2008); Lubin \& Esty (2010).

\section{Chart 1.}

CSR execution capacity per company (in \%)

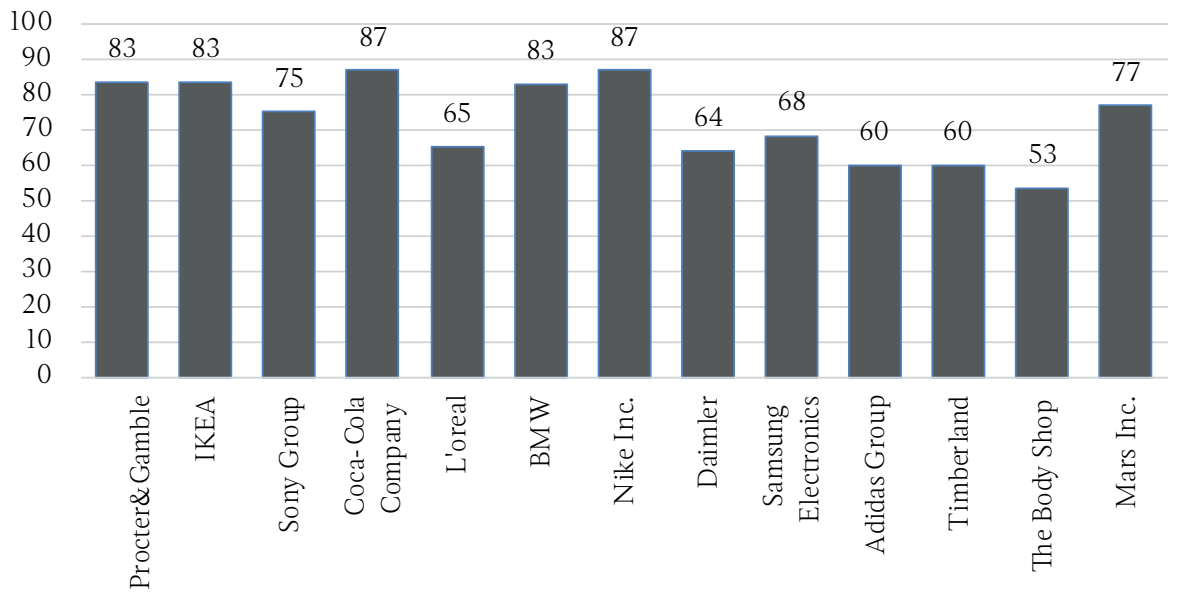

Source: Own preparation. 
Chart 2.

CSR value creation per company (in \%)

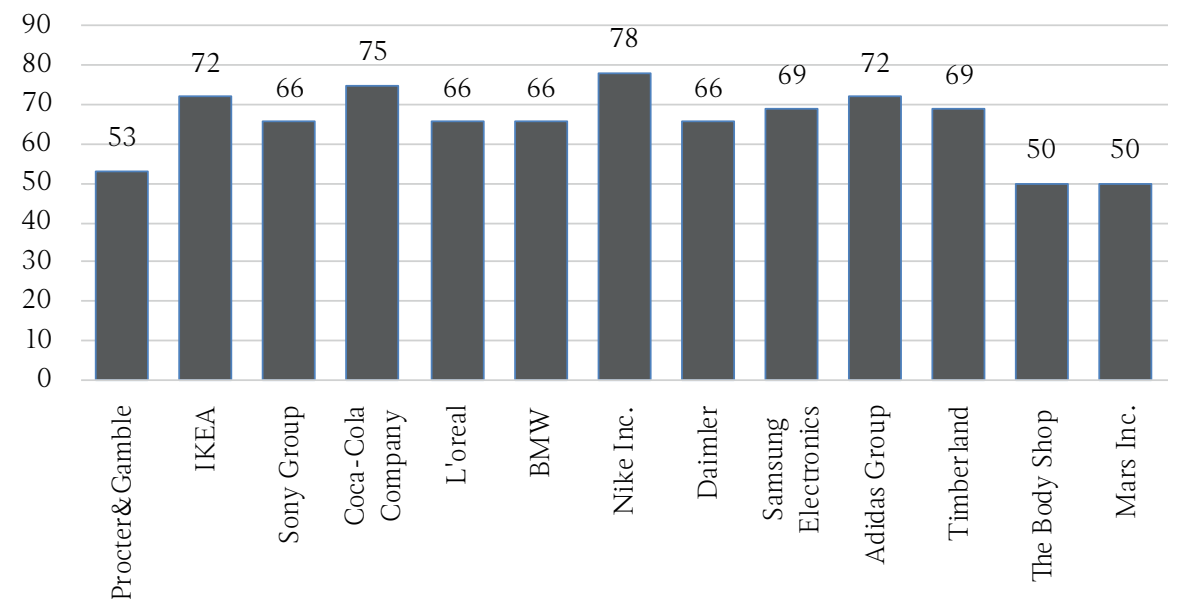

Source: Own preparation.

Chart 3.

Sustainability overall score per company (in \%)

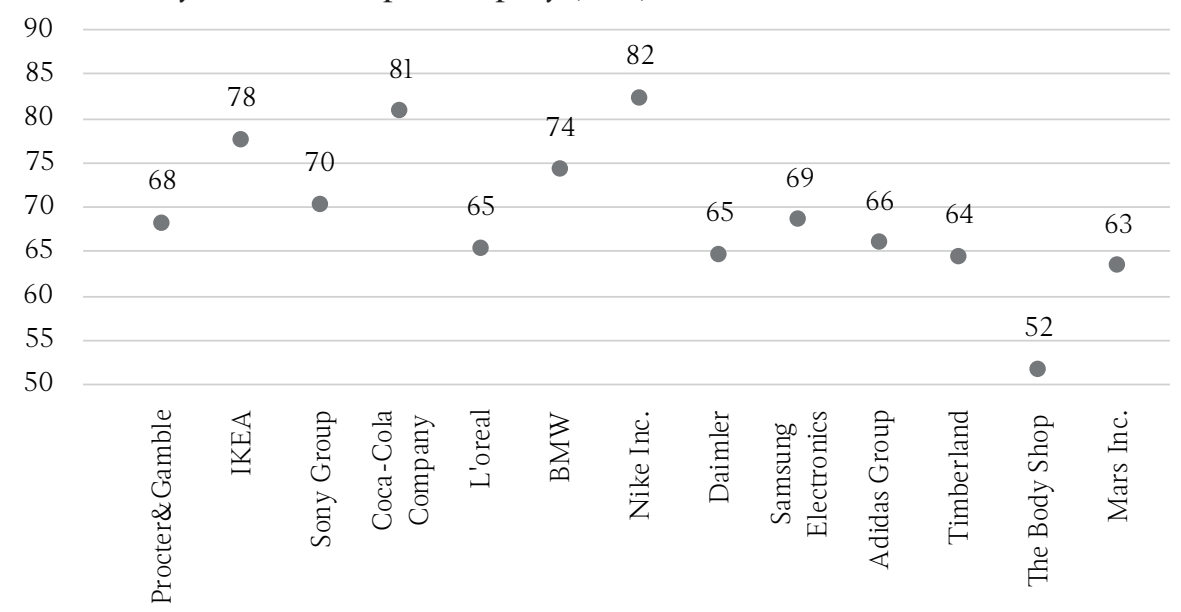

Source: Own preparation. 
